\title{
Pterosaur teeth from the Laje do Coringa, middle Cretaceous, São Luís- Grajaú basin, Maranhão state, Northern-Northeastern Brazil
}

\author{
Felipe Alves Elias ${ }^{1}$, Reinaldo J. Bertini ${ }^{1}$ \& Manuel Alfredo Araújo Medeiros ${ }^{2}$
}

\begin{abstract}
This contribution presents the partial results of an investigation plan of a reptile teeth set, collected from one of the richest and most diversified fossil deposits from the middle Cretaceous from the State of Maranhão, Brazil: the Laje do Coringa. Situated in the Cajual Island, Alcântara Municipality, it consists of bone-bed with an expressive fossil record, late Albian/early Cenomanian in age, belonging to the Alcântara Formation, São Luís-Grajaú Basin. Analysis of morphologic parameters of teeth crown suggests an association of at least four morphotypes to Ornithocheiroidea pterosaurs. Based on this interpretation, this group, which has a diversified record in the middle Cretaceous deposits from the Santana Formation, Araripe Basin, has now its first occurrence demonstrated in the São Luís-Grajaú Basin.
\end{abstract}

Keywords: teeth, Pterosauria, Laje do Coringa, Alcântara Formation, São Luís-Grajaú Basin

Resumo Dentes de pterossauros da Laje do Coringa, médio Cretáceo, bacia de São Luís-Grajaú, Estado do Maranhão, Norte-Nordeste do Brasil. Esta contribuição apresenta os resultados parciais de um plano de investigação de um conjunto de dentes de répteis, coletados de um dos mais ricos e diversificados depósitos fossilíferos do Cretáceo médio do Estado do Maranhão, Brasil: a Laje do Coringa. Situado na Ilha do Cajual, Município de Alcântara, consiste em um bone-bed com um expressivo registro fóssil, de idade neoalbiana/eocenomaniana, pertencente à Formação Alcântara, Bacia de São Luís-Grajaú. A análise de parâmetros morfológicos da coroa dos dentes sugere uma associação de pelo menos quatro morfótipos dentários a pterossauros Ornithocheiroidea. Baseada nesta interpretação, este grupo, que possui diversificado registro em depósitos cretácicos da Formação Santana da Bacia do Araripe, tem agora sua primeira ocorrência demonstrada na Bacia de São Luís-Grajaú.

Palavras-chave: dentes, Pterosauria, Laje do Coringa, Formação Alcântara, Bacia de São Luís-Grajaú

INTRODUTION The São Luís-Grajaú Basin had a genesis in part related to the fragmentation of Gondwana and the separation of South America and Africa (Góes \& Rossetti, 2001). Its total area is about 250.000 $\mathrm{km}^{2}$, with an expressive parcel enclosing the interior and the coast of State of Maranhão (Rossetti \& Góes, 2003). Its sedimentary sequence, of predominantly Cretaceous age, is very thick, reaching $4.000 \mathrm{~m}$ in Pinheiro Municipality region (Rossetti, 2001).

The Itapecuru Group, at the top of the stratigraphic sequence of the São Luís-Grajaú Basin, is composed by 3 lithostratigraphic unities, deposited during the Early Cretaceous (early Albian) to Late Cretaceous / Early Tertiary times (Rossetti \& Truckenbrodt, 1997). This particular succession strata contains an important fossil record of vertebrates, very promising for paleontological research.

The Alcântara Formation, the dominant lithostratigraphic unity exposed on the littoral cliffs of the North and Northeast State of Maranhão, contains the most diversified vertebrate fossil record known in the Itapecuru Group. It includes fish teeth and scales, turtle shells and especially isolated bones and teeth of cro- codylomorphs and dinosaurs. The assemblage seems to show several similarities with Cretaceous equivalents from the Northern and Northwestern Africa (Vilas Bôas et al., 1999; Medeiros \& Vilas Bôas, 1999; Dutra \& Malabarba, 2001; Moraes-Santos et al., 2001; Medeiros, 2001; Medeiros \& Schultz, 2001).

This contribution presents some results of the investigation of a set of reptile teeth, collected from one of the richest Cretaceous fossiliferous deposits of State of Maranhão: the Laje do Coringa. Situated in the Cajual Island, Alcântara Municipality, it consists of a bone-bed with expressive fossil record, correlated to the Alcântara Formation, late Albian to early Cenomanian in age (Medeiros, 2001; Medeiros \& Schultz, 2001, Holz, 2003).

Fossil teeth are abundant and of potential importance for taxonomy of vertebrates. In this paper we present results of analysis of nine isolated teeth. All specimens are very long and slender, with pointed tips and without carinae. Particular morphological features allowed the identification of four distinct morphotypes, all of them with probable affinities to pterosaurs of the Ornithocheiroidea clade sensu Kellner (2003). This 
contribution represents the first record of this group in Cretaceous deposits of the São Luís-Grajaú Basin.

GEOLOGICAL SETTING According to Rossetti (2001) the São Luís-Grajaú Basin (Fig. 1a) is a typical marginal rift basin, with predominantly Cretaceous filling (Fig. 1b). In its base there are lacustrine deposits of the Codó Formation and fluvial/deltaic deposits of the Grajaú Formation, both late Aptian in age. Above of this sequence there is a large package called Itapecuru Group, subdivided in three main lithostratigraphic unities: Indifferentiated Geological Unity (early to middle Albian), Alcântara Formation (late Albian to early Cenomanian) and Cujupe Formation (Late Cretaceous to Early Tertiary).

The Alcântara Formation, composed mainly by sandstones, mudstones and limestones with a thickness of 30-35 cm, was probably formed by large storms events and subordinately by tidal currents and waves, in an ancient transitional environment (Rossetti \& Truckenbrodt, 1997). It outcrops especially on the coastal line of North-Northeastern State of Maranhão, mainly at São Marcos Bay area (Fig. 1c). Palynological analysis, developed in deposits from a representative outcrop of the Alcântara Formation, near São Luís Municipality, evidenced a stratigraphic interval between late Albian and early Cenomanian in age (Pedrão et al., 1994).

The Laje do Coringa, one of the several outcrops of this area, is located on the Cajual Island (Fig. 1c), Alcântara Municipality, about $25 \mathrm{~km}$ on the West of São Luís Municipality (Martins 1996, 1997). The flagstone crops out on a discontinuous area of 4,000 $\mathrm{m}^{2}$, submitted to tidal variation that can exceed six meters. Continuous action of tidal waves resulted in an advanced weathering of the flagstone (Martins, 1997; Medeiros, 2001).

The Laje do Coringa succession strata are made up of by stratified sandstone and rhythmic sandstone/ mudstone facies, intercalated with conglomerate levels, composed by lithoclasts of quartz, metamorphic and igneous rocks, and bioclasts of fossil plants and vertebrates (Martins, 1996, 1997; Holz et al., 2001; Holz, 2003). According to Medeiros (2001) and Holz et al. (2001), the fossiliferous levels represent large accumulations of non-autochthonous fossil remains, transported by tidal currents to that site, where they were finally buried and fossilized. Medeiros \& Schultz $(2001,2002)$ suggest that although almost all of these fossil remains, especially the vertebrate fragments, may have belonged to animals that lived along a considerable time interval, they probably represent the same paleocommunity, since Maranhão continental fauna, at least partially, experienced continuance along early to mid-Albian and early Cenomanian, as documented by fossils from deposits in the Itapecuru inland and those from Alcântara Formation.

Some evidences also suggest intense reworking process on fossils, as result of base-level falls during transgression events, with subsequent action of waves and tidal currents (Holz et al., 2001; Holz, 2003) or, as suggested by Rossetti (personal communication,
2006), caused by the influence of high intensity storm episodes.

According to Rossetti (personal communication, 2006), similar evidences of large storm influence, in reworking process of sediments, may be observed at several outcrops on the margins of Itapecuru river, correspondent to the Indifferentiated Geological Unity sensu Rossetti \& Truckenbrodt (1997), early to middle Albian, near Coroatá Municipality, in the interior of Maranhão State. Although the Laje do Coringa is considered as part of the Alcântara Formation succession strata by several authors (Carvalho et al., 1997; Vilas Bôas et al., 1999; Medeiros \& Vilas Bôas, 1999; Medeiros, 2001; Medeiros \& Schultz, 2001), on the basis of similarity between the Laje do Coringa and the deposits of Coroatá region, Rossetti does not exclude the possibility of correlation between Laje do Coringa to older geological units.

MATERIALS AND METHODOLOGY The teeth set here analyzed consists of nine isolated specimens (Fig. 2) collected from the Laje do Coringa by research teams of the Universidade Federal do Maranhão (UFMA) and Centro de Pesquisa em História Natural e Arqueologia do Maranhão (CPHNAM), from 2000 to 2003. All specimens were found isolated, among broken blocks of sedimentary rock. Although they probably belong to one of the conglomeratic levels of the Laje do Coringa, as all other vertebrate remains were found in that site, it is difficult to establish their exact stratigraphic level.

Part of the teeth set (UFMA 1.20.178-1, UFMA 1.20.166, UFMA 1.20 .130 and UFMA 1.20.1744) is deposited in the scientific collection of the Departamento de Biologia da Universidade Federal do Maranhão (UFMA), São Luís Municipality, State of Maranhão. Another portion of the material (URC R.77-1, URC R.77-2, URC R.77-3, URC R.77-4 and URC R.77-5) is deposited in the scientific fossil collection of the Instituto de Geociências e Ciências Exatas da Universidade Estadual Paulista (UNESP), Rio Claro, State of São Paulo.

The specimens were analyzed according to morphological criteria, based on the following parameters:

(a) shape of dental crown,

(b) curvature of dental crown,

(c) degree of labio-lingual compression of crown,

(d) shape of tooth apex,

(e) shape of transversal section of crown,

(f) enamel ornamentation.

Analysis of the last parameter on all specimens was done under a Leica MZ6 Stereosmicroscope. The anatomical terminology used in this contribution is based on Smith \& Dodson (2003).

All characteristics observed in these specimens were compared with several references in the literature, as well to teeth preserved in dental alveoli of pterosaur skulls and jaws from the Santana Formation (Aptian/ 

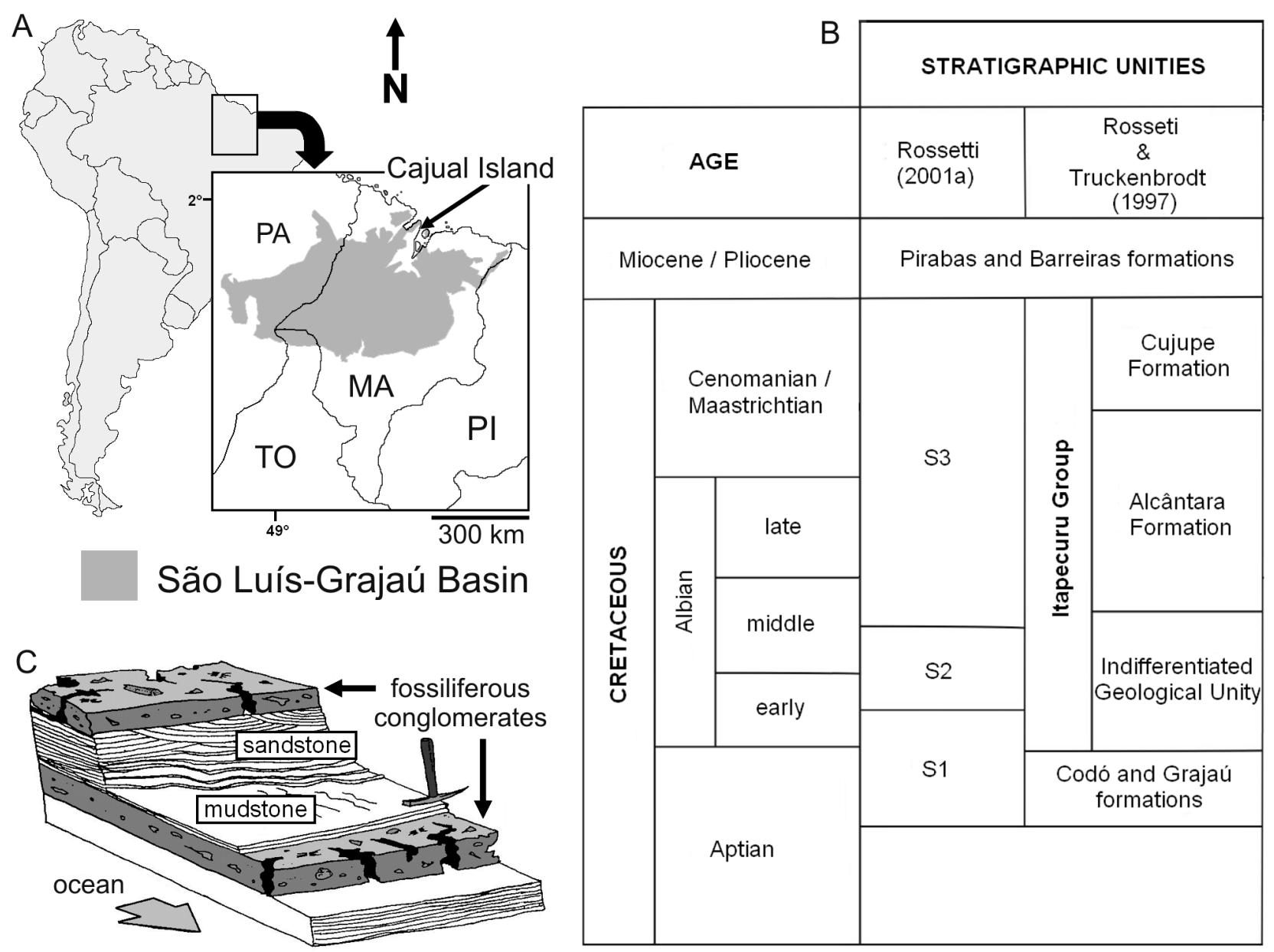

Figure 1 - Geological setting of the pterosaur teeth: (a) localization of the São Luis-Grajaú Basin and Cajual Island; (b) depositional model of the São Luis-Grajaú sequence; (c) schematical model of the Laje do Coringa.

Albian), housed in the scientific collection of the Departamento de Geologia e Paleontologia, Museu Nacional, Universidade Federal do Rio de Janeiro.

Institutional abbreviations.

UFMA, Universidade Federal do Maranhão, São Luís, MA;

URC, Universidade Estadual Paulista, Rio Claro, SP; MN, Museu Nacional, Universidade Federal do Rio de Janeiro, Rio de Janeiro.

\section{SYSTEMATIC PALAEONTOLOGY}

Pterosauria Kaup, 1834

Pterodactyloidea Plieninger, 1901

OrnithocheIROIDEA Kellner, 2003

Anhangueridae Campos \& Kellner, 1985

Morphotype 1

(Fig. 3)

Materials: UFMA 1.20.178-1, URC R.77-1, URC R.77-2, URC R.77-3, URC R.77-4 and URC R.77-5.

Description. Morphotype represented by six isolated teeth and crowns. Crown lengths range between 11.45 and $31.18 \mathrm{~mm}$. All specimens are long and slender, with pointed tips and no carinae. The crown is moderately recurved mesio-distally, but it is almost straight labio-lingually, from the base to the medial portion. Near the tip, the crown becomes slightly recurved lingually. They are characterized by a cross-section with oval shape. Surface of enamel is smooth on the labial and lingual surfaces.

Pterosauria Kaup, 1834

Pterodactyloidea Plieninger, 1901

Ornithocheiroidea Kellner, 2003

ANHANGUERIDAe Campos \& Kellner, 1985

Morphotype 2

(Fig. 4)

\section{Material: UFMA 1.20.166.}

Description. Morphotype is represented by a single specimen, an isolated crown. The crown is very long $(27.44 \mathrm{~mm})$ and slender, with pointed tip and no carinae. It is not recurved mesio-distally but is slightly recurved lingually. Cross section has an elliptical shape. Surface of enamel is smooth on the labial and lingual surfaces. Pterosauria Kaup, 1834 


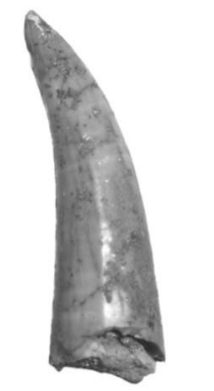

URC R.77-1

UFMA 1.20.178-1

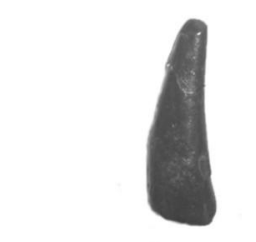

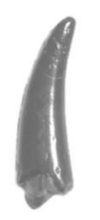

URC R.77-2

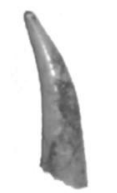

URC R.77-3

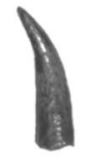

URC R.77-4

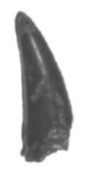

URC R.77-5

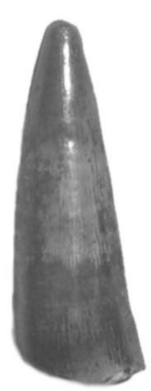

UFMA 1.20 .166

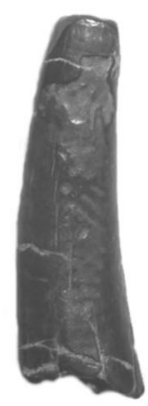

UFMA 1.20 .130

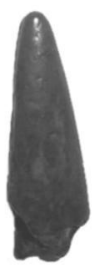

UFMA 1.20 .1744

$10 \mathrm{~mm}$

Figure 2-Pterosaur teeth set collected from the Laje do Coringa.
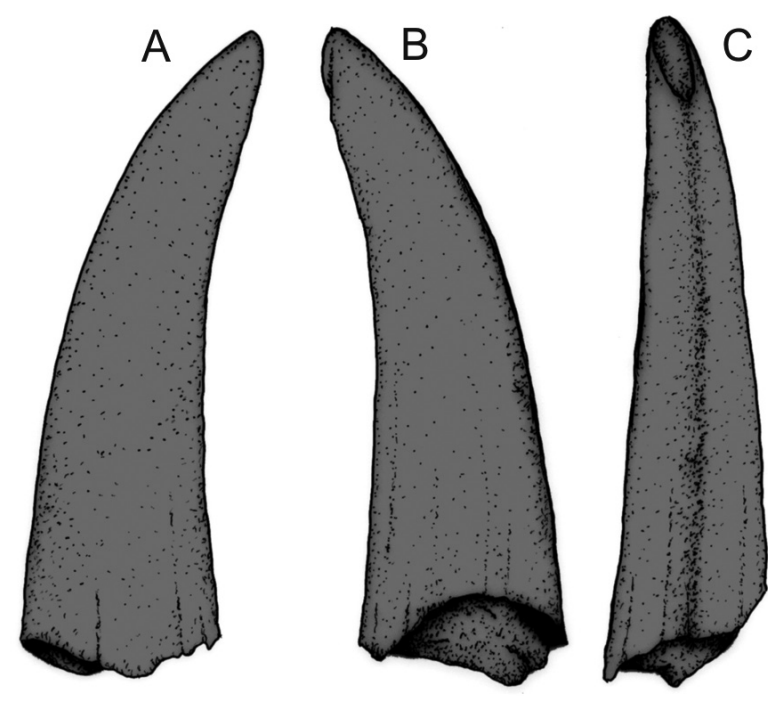

$10 \mathrm{~mm}$

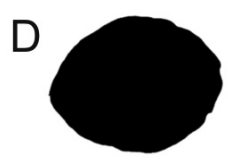

Figure 3 - URC R-77-1: (a) labial view; (b) lingual view; (c) distal view; (d) cross section view
Pterodactyloidea Plieninger, 1901

ORNithocheiroidea Kellner, 2003

Morphotype 3

(Fig. 5)

Material: UFMA 1.20.130.

Description. Morphotype represented by a single specimen, an isolated fragment crown. The crown is long $(30.04 \mathrm{~mm})$ and slender. The tip is broken and there is no evidence of carinae. The crown is slightly recurved mesio-distally and moderately recurved lingually, and has a very compressed and flattened cross-section, with a more elliptical shape than the previous morphotypes, and is lightly concave in the lingual surface. Enamel not preserved in almost the entire crown; the exposed dentine shows several breaking points and it is sculptured by fine and parallel wrinkles on the labial and lingual surfaces. A set of about seven thin, deep and straight ridges can be observed on the lingual surface, following parallel between themselves and diagonally in relation to the basal limit of the crown.

Pterosauria Kaup, 1834

Pterodactyloidea Plieninger, 1901

OrNithocheIROIDEA Kellner, 2003

Morphotype 4

(Fig. 6) 
A

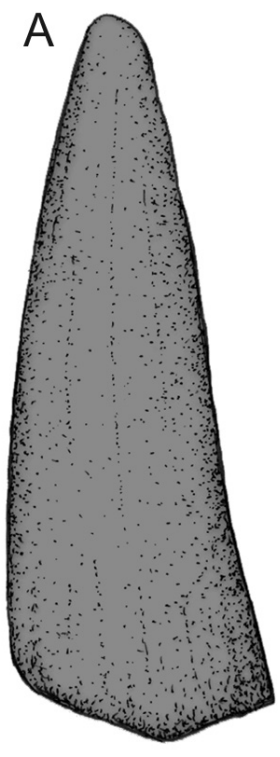

$10 \mathrm{~mm}$
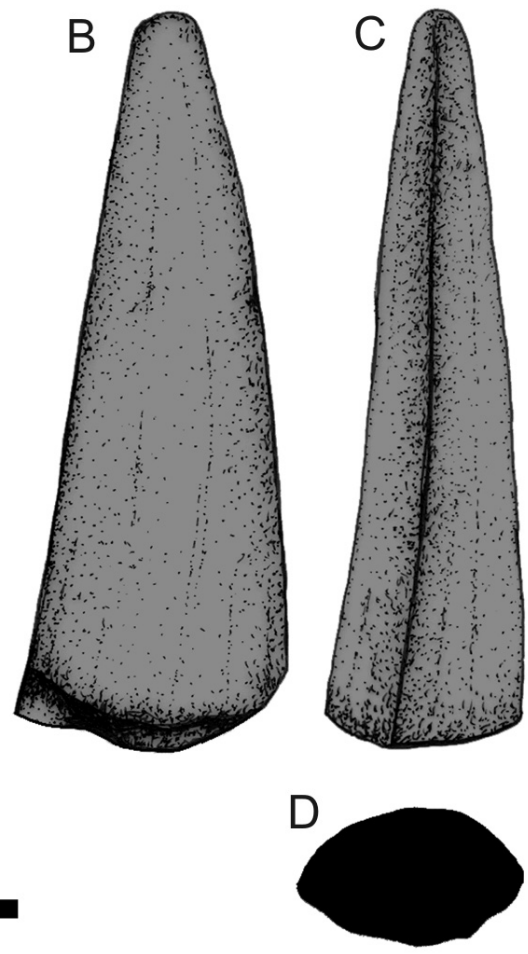

Figure 4-UFMA 1.20.166: (a) labial view; (b) lingual view; (c) mesial view; (d) cross section view
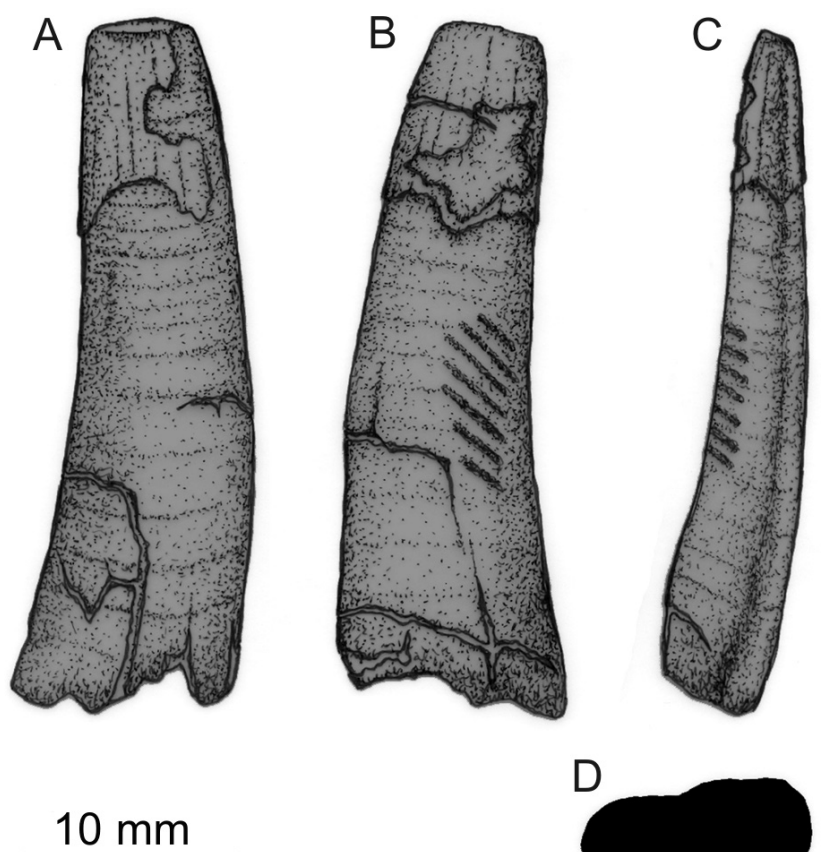

Figure 5 - UFMA 1.20.130: (a) labial view; (b) lingual view; (c) distal view; (d) cross section view.
Material: UFMA 1.20.1744.

Description. This morphotype is represented by a single specimen, an isolated fragmented crown. It is long $(19,73 \mathrm{~mm})$ and slender, with a triangular general shape. The tip is sharp and slightly rounded. There is no evidence of carinae on the entire surface of the preserved crown. The crown is straight mesio-distally and moderately recurved lingually. It has a very compressed and flattened cross-section, with an elliptical shape. The surface of the enamel is smooth on the labial and lingual surfaces.

DISCUSSION Teeth with very long and slender crowns and pointed tips occur in different groups of Mesozoic reptiles, including several Jurassic plesiosauroids and tallatosuchians, as well some Cretaceous pterosaurs and theropod dinosaurs, particularly spinosaurids (Massare, 1987; Holtz Jr., 1998).

All specimens analyzed show moderately to strong labio-lingually compressed crowns, smooth enamel surfaces (except Morphotype 3) and no carinae. The absence of typical longitudinal and parallel ridges patterns on the enamel surfaces, and an expanded labio-lingually crown, does not support an affinity with plesiosauroids (Massare, 1987; Brown \& Cruickshank, 1994; Carpenter, 1996; Storrs \& Taylor, 1996; Gasparini, 1997; Kear, 2006). These characteristics, plus the absence of carinae on both mesial and distal edges, either do not support affiliation to tallatosuchians, a group of crocodylomorphs with chronological distribution from Callovian to Neocomian (Willinston, 2000) or spinosaurids, theropod dinosaurs also recorded in the Laje do Coringa by teeth material (Medeiros \& Vilas Bôas, 1999; Medeiros, 2001; Medeiros \& Schultz, 2001).

The combination of characters observed in all four morphotypes is more consistent with teeth morphology of some toothed Cretaceous pterosaurs, especially Anhangueridae (Wellnhofer 1985, 1987).

To establish comparisons with taxonomic purpose were analyzed some ornithocheiroids specimens coming from the Aptian/Albian deposits of the Santana Formation, Araripe Basin, including skull and jaw elements associated with teeth, deposited in the scientific collection of the Museu Nacional, Rio de Janeiro:

(a) MN 4805-V (Anhanguera blittersdorffi);

(b) MN 4735-V (Anhanguera araripensis sensu Kellner \& Tomida, 2000 but Coloborhynchus araripensis sensu Wellnhofer, 1985);

(c) MN 5023-V (skull cast - Anhanguera piscator sensu Kellner \& Tomida, 2000 but Coloborhynchus piscator sensu Veldmeijer, 2006);

(d) MN 4736-V (skull cast - Tropeognathus mesembrinus sensu Wellnhofer, 1987 and Kellner \& Tomida, 2000 but Criorhynchus mesembrinus sensu Fastnacht, 2001); 

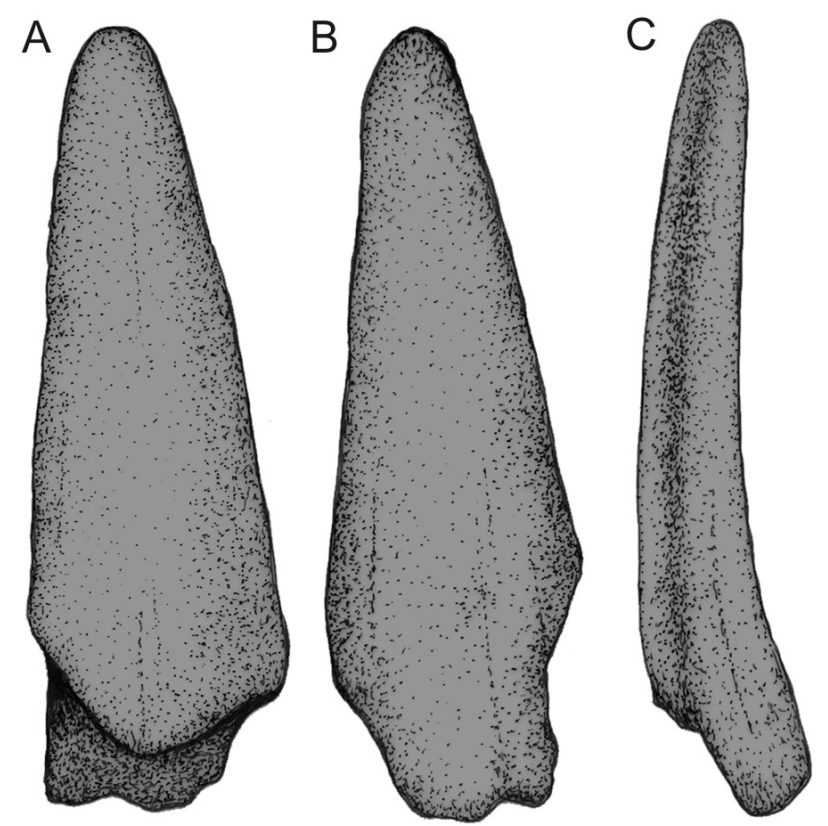

$10 \mathrm{~mm}$

D

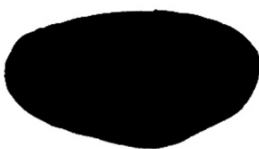

Figure 6-UFMA 1.20.1744: (a) labial view; (b) lingual view; (c) mesial view; (d) cross section view.

(e) MN 4804-V (Brasileodactylus araripensis);

(f) MN 4797-V (Brasileodactylus cf. araripensis).

Several remains of pterosaurs of the clades Anhangueridae, Criorhynchidae and Ornithocheiridae published in the literature were also analyzed, including skull and jaw elements also proceeding from the Santana Formation (Veldmeijer, 2006) and isolated teeth coming from continental Albian-Cenomanian deposits from Morocco, Northwestern Africa (Kellner \& Mader, 1997; Wellnhofer \& Buffetaut, 1999).

Based on studied specimens, Anhangueridae teeth may vary slightly in size and shape, depending on their position in the jaws. In the specimens assigned to the anhanguerid clade (Fastnacht, 2001; Veldmeijer, 2006), as well in MN 5023-V, premaxillary teeth tend to be bigger than others, moderately mesio-distally recurved and lightly lingually recurved (especially near the apex), with pointed tips and oval cross-section (see Kellner, 2003). All these characteristics are shared by specimens UFMA 1.20.178-1, URC R.77-1, URC R.77-2, URC R.77-3, URC R.77-4 and URC R.77-5, suggesting that they can be correlated with this group. Size range among these specimens could probably be associated with individual size variation.

As also observed in Anhangueridae, lateral teeth are not very different from premaxillary teeth, but tend to be a little shorter, almost straight mesio-distally, lighly recurved lingually and with a rounded, but softly compressed, elliptical cross-section. These characteristics are observed in UFMA 1.20.166 too, suggesting that it can be correlated with this group.

Although there are publications suggesting the presence of soft longitudinal ridges covering the surface of the enamel in some Anhangueridae teeth, as observed in other descriptions and some of the specimens used in these comparisons, there are some teeth not showing this kind of enamels ornamentation, including UFMA 1.20.166, UFMA 1.20.178-1, URC R.77-1, URC R.77-2, URC R.77-3, URC R.77-4 and URC R.77-5. Thus, considering the combination of all the characteristics observed in this analysis, the specimens UFMA 1.20.166, UFMA 1.20.178-1, URC R.77-1, URC R.77-2, URC R.77-3, URC R.77-4 and URC R.77-5 can be tentatively assigned to the Anhangueridae clade.

According to Kellner \& Tomida (2000) the ornithocheirids of the Criorhynchidae clade seem to show a relative homogeneity in size and shape of teeth in their dental assemblage, what distinct from the Anhangueridae, that show some heterodonty. The only tooth observed in the skull (cast MN 4736-V) shows some similarities with typical Anhangueridae teeth, but differs is in being slightly shorter and in cross-section. Its lingual surface is very flattened and its labial surface very rounded, resulting in an asymmetrical shape. Cross section of teeth of Anhangueridae analyzed tends to be more symmetrical on both sides. Lingual and labial surfaces are rounded and, in some cases, slightly flattened. None of the Laje do Coringa specimens show these characteristics, and therefore, an association of them to the Criorhynchidae does not seem probable.

In contrast above described specimens, UFMA 1.20.130 and UFMA 1.20.1744 show crowns hardly labio-lingually compressed, slightly recurved mesio-distally and moderately recurved lingually, conditions more typical of MN 4797-V and evidenced by alveoli morphology in MN 4804-V (labio-lingual compression).

A single pterosaur tooth, sharing the above features, collected in the Ksar es Souk Province, Morocco, was also described by Kellner \& Mader (1997). Wellnhofer \& Buffetaut (1999) described several pterosaur material proceeding from Hamada du Guir, Southern Morocco, including about thirty isolated, labio-lingually compressed teeth. According to the authors of both papers all materials belong to the same geological context, the Kem Kem deposits, probably late Albian to early Cenomanian in age.

Kellner \& Mader (1997) tentatively attributed their specimen to Anhangueridae and Wellnhofer \& Buffetaut (1999) to Ornithocheiridae. Morphotypes described by Wellnhofer \& Buffetaut (1999) do not show any particular difference from the single tooth described by Kellner \& Mader (1997). In the opinion of the authors of this present contribution, considering their similar morphology and geological context, it is very probable that both materials belong to the same group of pterosaurs.

As in the materials described by Wellnhofer 
Table 1-Morphological characterization of the four pterosaur teeth morphotypes analyzed.

\begin{tabular}{|c|c|c|c|c|}
\hline & Morphotype 1 & Morphotype 2 & Morphotype 3 & Morphotype 4 \\
\hline Shape of dental crown & Long and slender & Long and slender & Long and slender & Long and slender \\
\hline Curvature of dental crown & $\begin{array}{l}\text { Moderately recurved } \\
\text { mesio-distally and } \\
\text { almost straight labio- } \\
\text { lingually }\end{array}$ & $\begin{array}{l}\text { Straight mesio- } \\
\text { distally but is slightly } \\
\text { recurved lingually }\end{array}$ & $\begin{array}{l}\text { Slightly recurved } \\
\text { mesio-distally and } \\
\text { moderately recurved } \\
\text { lingually }\end{array}$ & $\begin{array}{c}\text { Straight mesio- } \\
\text { distally and } \\
\text { moderately recurved } \\
\text { lingually }\end{array}$ \\
\hline $\begin{array}{l}\text { Degree of labio-lingual } \\
\text { compression of crown }\end{array}$ & $\begin{array}{c}\text { Not very compressed } \\
\text { Pointed }\end{array}$ & $\begin{array}{l}\text { Not very compressed } \\
\text { Pointed }\end{array}$ & $\begin{array}{l}\text { Very compressed and } \\
\text { flattened }\end{array}$ & $\begin{array}{l}\text { Very compressed and } \\
\text { flattened }\end{array}$ \\
\hline Shape of tooth apex & Oval & Elliptical & Broken & $\begin{array}{l}\text { Sharp and slightly } \\
\text { rounded }\end{array}$ \\
\hline $\begin{array}{l}\text { Shape of transversal } \\
\text { section of crown }\end{array}$ & & & $\begin{array}{l}\text { Elliptical (more } \\
\text { compressed than } \\
\text { Morphotype 2) }\end{array}$ & $\begin{array}{l}\text { Elliptical (more } \\
\text { compressed than } \\
\text { Morphotype 2) }\end{array}$ \\
\hline Enamel ornamentation & $\begin{array}{l}\text { Smooth on the labial } \\
\text { and lingual surfaces / } \\
\text { without carinae }\end{array}$ & $\begin{array}{l}\text { Smooth on the labial } \\
\text { and lingual surfaces / } \\
\text { without carinae }\end{array}$ & $\begin{array}{l}\text { Enamel not preserved } \\
\text { in almost the entire } \\
\text { crown / without } \\
\text { carinae }\end{array}$ & $\begin{array}{l}\text { Smooth on the labial } \\
\text { and lingual surfaces / } \\
\text { without carinae }\end{array}$ \\
\hline
\end{tabular}

\& Buffetaut (1999), the enamel surface of UFMA 1.20.1744 is almost smooth. UFMA 1.20 .130 does not show a good preservation of its enamel, difficulting the observation of any kind of ornamentation. Its dentine shows a singular pattern of light wrinkles, resembling some teeth described by Wellnhofer \& Buffetaut (1999). On the thin diagonal ridges on the lingual surface of its dentine, no equivalent pattern was noticed. Considering the intense transportation and reworking processes that affected teeth before they were deposited in the sediments that originated the Laje do Coringa, it is possible that these ridges did not have a biological origin. In contrast MN 4797-V, and the African single tooth described by Kellner \& Mader (1997), seem to show a particular pattern of very light longitudinal ridges in their enamel. However the morphologic pattern in all cases is flagrantly similar.

The general morphology of UFMA 1.20.1744 and UFMA 1.20.130 differs significantly from features found in $\mathrm{MN} 5023-\mathrm{V}$ and other typical anhanguerids analyzed from the literature. Therefore their assignment to this clade seems less probable. In the same way, specimens from the Laje do Coringa show few characteristics in common with MN 4736-V, invalidating an association with Tropeognathus.

UFMA 1.20.1744 and UFMA 1.20 .130 show several morphological characteristics that resemble closely dental elements found in MN 4797-V (Brasileodactylus cf. araripensis). Brasileodactylus was first described by Kellner (1984) and assigned to the Ornithocheiridae.

The systematics of all ornithocheiroid groups is very problematic (Kellner \& Tomida, 2000). Many authors do not recognize the Anhangueridae clade and prefer to consider it as a junior synonymous of the Ornithocheiridae. Kellner \& Tomida (2000) suggested that Ornithocheiridae could be differentiated from Anhangueridae and Criorhynchidae by the absence of typical sagittal and mandibular crests that are present in these particular clades. The remains assigned to the Brasileodactylus genus (MN 4804-V and MN 4797-V) do not show evidence of sagittal or mandibular crests. Kellner \& Tomida (2000) suggested that Brasileodactylus does not belong to the Anhangueridae, but represents a sister group, based on the expansion of the rostral end of the dentary, a shared characteristic.

African morphotypes described by Wellnhofer \& Buffetaut (1999) also show several similarities with UFMA 1.20.1744 and UFMA 1.20.130. It is plausible, therefore, that UFMA 1.20.1744 and UFMA 1.20.130, as well the African pterosaur teeth set belong to an ornithocheiroid group closely related with Brasileodactylus..

CONCLUSIONS The pterosaur record in the Brazilian territory is until now limited to the Cretaceous deposits from Northeastern Brazil. The first mention of possible pterosaur materials was made by Arthur Smith Woodward in 1891, based in two quadrate bones proceeding from the Bahia Group, near Salvador Municipality, State of Bahia. Later on Woodward recognized them as bones of large coelacanthids (Price, 1953).

Price (1953) described the first unquestioned pterosaur remain found in Brazil, a left humerus fragment, proceeding from the Fazenda Congo locality, near the right margin of the Gramame River, State of Paraíba. Price (1953) assigned this bone, collected in rocks of the Gramame Formation (Maastrichtian), to 
the genus Nyctosaurus. Kellner (2006) considered that this particular material belongs to a distinct nyctosaurid genus.

The second record of pterosaurs in Brazil was also made by Price (1971), based in a fragment of a right anterior member found in a calcareous nodule from the Romualdo Member, Santana Formation, Araripe Basin, State of Ceara. So far, the Santana Formation (Aptian/Albian) showed itself as a promising field for the study of pterosaurs in Brazil, concentrating the attention of the academic community both inside and outside Brazil.

According to several recent reviews (Kellner \& Tomida, 2000; Fastnacht, 2001; Veldmeijer, 2006), dozens of important specimens of pterosaurs proceed from the Crato and Romualdo members of the Santana Formation, a part of a large pterosaurs assemblage of which Ornithocheiroidea seems to represent a significant parcel.

The occurrence of pterosaurs in the São LuísGrajaú Basin extends the geographic distribution of this group in the Brazilian sedimentary basins.

Morphological similarities found among some of the specimens here analyzed and morphotypes proceeding from North African deposits suggest a closer paleobiogeographic relationship between pterosaur assemblages from South America and Africa during the transition from Early to Late Cretaceous. Although the connection of North and South Atlantic, and the respective separations of both paleoenvironments began probably during the Early Cretaceous times (Ponte \& Asmus, 1976; Petri, 1987), it can be expected that flying vertebrates, with high flight abilities as pterosaurs could have spread widely along both sides of the narrow ocean. Thus, the similarities between South American and African fossil records reported in this work are not surprising.

Acknowledgments This contribution is a part of a MSc Dissertation by the first author, submitted to the Universidade Estadual Paulista (UNESP), under the direction of the second author. Authors wish to thank Conselho Nacional de Desenvolvimento Científico e Tecnológico $(\mathrm{CNPq})$ for the financial support and Universidade Estadual Paulista (UNESP), Universidade Federal do Maranhão (UFMA) and Centro de Pesquisa em História Natural e Arqueologia do Maranhão (CPHNAM), for additional support. They also wish to acknowledge Alexander Wilhelm Armin Kellner and his team, for access permission to examine pterosaur material deposited in the scientific collection of the Departamento de Geologia e Paleontologia, Museu Nacional, Universidade Federal do Rio de Janeiro.

\section{References}

Brown D.S. \& Cruickshank A.R.I. 1994. Skull of the Callovian plesiosaur Cryptoclidus eurymerus, and the sauropterygian cheek. Palaeontology, 37:941-953.

Carpenter K. 1996. A Review off short-necked plesiosaurs from the Cretaceous of the Western interior, North America. N. Jb. Geol. Paläont. Abh., 201:59-287.

Carvalho I. S., Vilas Bôas I. C. C., Berqvist L. P. 1997. Plesiossauros da região Equatorial Brasileira, Bacia de São Luís (Cretáceo Superior), Brasil. In: SPB, Congr. Bras. Paleo., 15, Resumos, p. 93.

Dutra M.F.A. \& Malabarba C.S.L. 2001. Peixes do AlbianoCenomaniano do Grupo Itapecuru no Estado do Maranhão, Brasil. In: Rossetti D.F., Góes A.M., Truckenbrodt W. (eds.) O Cretáceo na Bacia de São Luís-Grajaú. Coleção Friedrich Katzer, Ed. Museu Paraense Emílio Goeldi, p. 191-208.

Fastnacht M. 2001. First record of Coloborhynchus (Pterosauria) from the Santana Formation (Lower Cretaceous) of the Chapada do Araripe, Brazil. Paläont. Z, 75:2336.

Gasparini Z. 1997. A new plesiosaur from the Bajocian of the Neuquén Basin, Argentina. Palaeontology, 40:135-147.

Góes A.M. \& Rossetti D.F. 2001. Gênese da Bacia de São Luís-Grajaú, Meio Norte do Brasil. In: Rossetti D.F., Góes A. M., Truckenbrodt W. (eds.) O Cretáceo na Bacia de São Luis-Grajaú. Coleção Friedrich Katzer, Ed. Museu Paraense Emílio Goeldi, p. 15-29.

Holz M. 2003. Sequence stratigraphy as a tool for Vertebrate Taphonomy - an example from the late Cretaceous di- nossaur taphoccoenosis from São Luis Basin, Northern Brazil. In: MPEG, Latinamerican Congress of Sedimentology, 3, Abstracts, p. 213-214.

Holz M., Medeiros M.A.A., Schultz C.L. 2001. Tafocenoses de vertebrados formando resíduos transgressivos - o exemplo do sítio fossilífero "Laje do Coringa" do Neocretáceo da Bacia de São Luís no Norte do Brasil. In: SBP, Congr. Bras. Paleo., 17, Boletim, p. 36.

Holtz Jr., T.R. 1998. Spinosaurs as Crocodile Mimics. Science, 282:1276-1277.

Kear B.Q. 2006. Plesiosaur remains from Cretaceous highlatitude non-marine deposits in Southeastern Australia. J. Vert. Paleontology, 26:196-199.

Kellner A.W.A. 1984. Ocorrência de uma mandíbula de Pterosauria (Brasileodactylus araripensis, nov. gen.; nov. sp) na Formação Santana, Cretáceo da Chapada do Araripe, Ceará -Brasil. In: SBG, Congr. Bras. Geo, 33, Anais, p. 578-591.

Kellner A.W.A. 2003. Pterosaur phylogeny and comments on the evolutionary history of the group. In: Buffetaut E. \& Mazin J.M. (eds.) Evolution and Palaeobiology of Pterosaurs. Geological Society, Special Publication 217, p. 105-137.

Kellner A.W.A. 2006. Pterossauros - os senhores do céu do Brasil. Vieira \& Lent, Rio de Janeiro, $176 \mathrm{p}$.

Kellner A.W.A. \& Mader B.J. 1997. Archosaur teeth from the Cretaceous of Morocco. J. Paleontology, 71:525-527.

Kellner A.W.A. \& Tomida Y. 2000. Description of a new species of Anhangueridae (Pterodactyloidea) with com- 
ments of the pterosaur fauna from the Santana Formation (Aptian-Albian), Northeastern Brazil. Tokyo, National Science Museum Monographs, 17, 138p.

Martins F.J.C. 1996. Levantamento de aspectos geológicos da parte Setentrional da Ilha de São Luís e áreas adjacentes. Dissertação de Mestrado, Instituto de Geociências, Universidade Federal do Rio de Janeiro, 98 p.

Martins F.J.C. 1997. A Laje do Coringa: um bone-bed da Formação Itapecuru (Cretáceo Superior da Bacia de São Luís - MA). An. Acad. Bras. Ci., 69:436-437.

Massare J.A. 1987. Tooth morphology and prey preference of Mesozoic marine reptiles. J. Vert. Paleontology, 7: 121-137.

Medeiros M.A. 2001. A Laje do Coringa (Ilha do Cajual, Bacia de São Luís, Baía de São Marcos, MA): conteúdo fossilifero, Bioestratinomia, diagênese e implicações na Paleobiogeografia do meso-Cretáceo do Nordeste brasileiro. Tese de Doutoramento, Instituto de Geociências, Universidade Federal do Rio Grande do Sul, 137 p.

Medeiros M.A. \& Schultz C.L. 2001. Uma paleocomunidade de vertebrados do Cretáceo médio, Bacia de São Luís. In: Rossetti D.F., Góes A.M., Truckenbrodt W. (eds.) $O$ Cretáceo na Bacia de São Luís-Grajaú. Coleção Friedrich Katzer, Ed. Museu Paraense Emílio Goeldi, p. 209221.

Medeiros M.A. \& Schultz C.L. 2002. A fauna dinossauriana da "Laje do Coringa", Cretáceo Médio do Nordeste do Brasil. Arquivos do Museu Nacional, 60:155-162.

Medeiros M.A. \& Vilas Bôas I.C.C. 1999. A Laje do Coringa: uma paleocomunidade continental do Cenomaniano do Nordeste do Brasil. In: SBP, Congr. Bras. Paleo., 16, Resumos, p.70-71.

Moraes-Santos H.M., Mello C.C.S., Toledo P.M., Rossetti D. F. 2001. Ocorrência de Pleurodira na Formação Alcântara (Albiano-Cenomaniano), Bacia de São Luís-Grajaú, MA. In: Rossetti D.F., Góes A.M., Truckenbrodt W. (eds.) O Cretáceo na Bacia de São Luís-Grajaú. Coleção Friedrich Katzer, Ed. Museu Paraense Emílio Goeldi, p. 235-244.

Pedrão E., Arai M., Carvalho I.S., Ferreira C.S. 1994. Palinomorfos de sedimentos albianos (Formação Itapecuru) da bacia do Parnaíba. An. Acad. Bras. Ciencias, 66:118.

Petri S. 1987. Cretaceous paleogeographic maps of Brasil. Palaeogeography, Palaeoclimatology, Palaeoecology, 59:117-168.

Ponte F.C. \& Asmus H.E. 1976. The Brazilian marginal basins: current state of knowledge. An. Acad. Bras. Ci., 48: 215-240.

Price L.I. 1953. A presença de Pterosauria no Cretáceo Supe- rior do Estado da Paraíba. Notas Preliminares Estudos, Divisão Geologia do DNPM, 71:1-12.

Price L.I. 1971. A presença de Pterosauria no Cretáceo Inferior da Chapada do Araripe, Brasil. Acad. Bras. Ci., 43: 451-461.

Rossetti D.F. 2001. Arquitetura deposicional da Bacia de São Luís-Grajaú. In: Rossetti D.F., Góes A.M., Truckenbrodt W. (eds.) O Cretáceo na Bacia de São Luís-Grajaú. Coleção Friedrich Katzer, Ed. Museu Paraense Emílio Goeldi, p. 31-46.

Rossetti D.F. \& Góes A.M. 2003. Caracterização paleoambiental de depósitos albianos na borda Sul da Bacia de São Luís-Grajaú: modelo de delta fluvial influenciado por tempestade. Revista Brasileira de Geociências, 33: 299-312.

Rossetti D.F. \& Truckenbrodt W. 1997. Revisão estratigráfica para os depósitos do Albiano - Terciário Inferior (?) na Bacia de São Luís (MA), Norte do Brasil. Boletim do Museu Paraense Emílio Goeldi (Série Ciências da Terra), 9:29-41.

Smith J. B. \& Dodson P. 2003. A proposal for a standard terminology of anatomical orientation in fossil vertebrrate dentitions. J. Vert. Paleontology, 23:1-12.

Storrs G.W. \& Taylor M.A. 1996. Cranial anatomy of a new plesiosaur genus from the lowermost Lias (Rhaetian/ Hettangian) of Street, Somerset, England. J. Vert. Paleontology, 16:403-420.

Veldmeijer A.J. 2006. Toothed pterosaurs from the Santana Formation (Cretaceous; Aptian-Albian) of northeastern Brazil. A reappraisal on the basis of newly described material. Proefschrift Universiteit Utrecht, Munich, 268 p.

Vilas Bôas, I. C. C., Carvalho, I. S., Medeiros, M. A., Pontes, H. 1999. Dentes de Carcharodontosaurus (Dinosauria: Tyrannosauridae) do Cenomaniano, Bacia de São Luís (Norte do Brasil). An. Acad. Bras. Ci., 71: 846-847.

Wellnhofer P. 1985. Neue Pterosaurier aus der Santana-Formation (Apt) der Chapada do Araripe, Brasilien. Palaontographica, 187:105-182.

Wellnhofer P. 1987. New crested pterosaurs from the Lower Cretaceous of Brazil. Mitt. Bayer. Staatsslg. Paläont. hist. Geol., 27:175-186.

Wellnhofer P. \& Buffetaut E. 1999. Pterosaur remains from the Cretaceous of Morocco. Paläont. Z., 73:133-142.

Willinston S.W. 2000. Water Reptiles of the Past and Present. Arment Biological Press, Landisville, $156 \mathrm{p}$.

Manuscrito AE - 069-2006

Recebido em 08 de fevereiro de 2007 Aceito em 01 dezembro de 2007 